\title{
Resistensutvikling må overvåkes - gonokokken som eksempel
}

\author{
Utbredt bruk og feilbruk av antibiotika fører til økning av resistente bakteriestammer. Gonokokken har vist \\ seg kapabel til en rask resistensutvikling, og det er grunn til å frykte at vi vil mangle effektiv behandling av \\ gonoré i løpet av neste decennium. Systematisk overvåking gjennom nasjonalt og internasjonalt samarbeid \\ er avgjørende for å forebygge spredning av resistente stammer og sikre effektiv behandling.
}

Allerede kort tid etter at antibiotika kom på markedet, i tiden rundt den annen verdenskrig, ble det klart at mikrobene tilpasser seg vår bruk av antibakterielle midler (1). Utviklingen av antibiotikaresistens hos gonokker er et godt eksempel på dette.

Gonokokken deler seg raskt og kan behandles med en engangsdose antibiotika. Allerede i 1960-årene ble det observert kromosomal resistens mot penicillin. I begynnelsen av 1970-årene ble behandlingen endret - fra injeksjon av benzylpenicillin til bruk av bredspektrede perorale penicilliner. For å øke effekten gjennom forsinket renal utskilling ble det gitt $1 \mathrm{~g}$ probenecid i tillegg til $1 \mathrm{~g}$ ampicillin.

I 1976 kom den første rapporten om fullstendig resistens mot penicilliner gjennom et plasmid, penicillinaseproduserende Neisseria gonorrhoeae (PPNG) (2), men det tok tid før disse stammene spredte seg. I midten av 1980-årene var kombinasjonen av ampicillin og probenecid fortsatt effektiv behandling, men etter hvert så man økende behandlingssvikt. Forekomsten av den tidligere dominerende og penicillinfølsomme serotypen WI sank og ble erstattet av gonokokkstammer med serotype WII/WIII $(3,4)$, med økende kromosomal resistens mot betalaktamer. Tilfredsstillende behandlingsrespons ble oppnådd ved å øke dosen av amoksicillin til $2 \mathrm{~g}$ (4).

Dette vedvarte til slutten av 1980-årene. Da hadde PPNG-stammer med total penicillinresistens spredt seg i Norge (5). Fluorokinoloner, spesielt ciprofloksacin, ble innført som førstehåndsmiddel (6), selv om det allerede i 1990 kom advarsler mot ukritisk bruk (7). Anbefalingen av fluorokinolon sto likevel ved lag frem til de nasjonale retningslinjene ble endret i 2012 (8). Allerede i 2005 fant man ved Olafiaklinikken i Oslo det nødvendig å bytte til et tredjegenerasjons peroralt kefalosporin (cefixime), og så i 2009 til ceftriaksoninjeksjon, etter at det ble påvist behandlingssvikt og resistens mot cefixime (9).

Spektinomycin har helt siden 1970-årene vært et «siste skanse»-medikament ved resistent gonokokkinfeksjon (10). Det er derfor urovekkende at det første tilfellet med resistens også mot spektinomycin ble registrert ved Olafiaklinikken i 2010 (11). I Internasjonale retningslinjer anbefales det nå å behandle gonokokkinfeksjoner med en kombinasjon av to antibiotika - ceftriakson og azitromycin (12).

Forekomsten av gonokokkinfeksjoner er lav i Norge, men resistente mikrober sprer seg raskt fra andre land, særlig Sørøst-Asia. Resistensutviklingen er illustrerende for interaksjonen mellom mikrobe og medikamentbruk. Gjennom ukritisk bruk av antibiotika, særlig i suboptimale doser, utvikler mikrobene gjennom mutasjoner kromosomal resistens, men de kan også plukke opp resistensgener fra andre bakterier (13-15).

For en del mikrobielle agenser er det etablert nasjonale referanselaboratorier for å kvalitetssikre diagnostikken og gi mulig-

\section{«Gjennom ukritisk bruk av antibiotika, særlig i suboptimale doser, utvikler mikrobene \\ gjennom mutasjoner \\ kromosomal resistens»}

heter for faglig oppfølging. For å stå bedre rustet dersom multiresistente gonokokker $(16,17)$ skulle dukke opp i Norge bør det derfor nå etableres et nasjonalt referanselaboratorium for gonokokker, med faglig ekspertise og adekvat finansiering, slik at bl.a. alle gonokokkstammer blir enhetlig resistenstestet.

Rapportering av antibiotikaresistensutvikling er viktig (18). Slike rapporter finnes bl.a. på nettsiden til Universitetssykehuset Nord-Norge (19). Feilbruk av antibiotika kan motarbeides ved å følge utviklingen og om nødvendig endre bruken av disse viktige legemidlene.

Kjetil K. Melby
k.k.melby@medisin.uio.no
Anne O. Olsen
Lumnije Dedi
Peter Gaustad
Gaute Syversen
Harald Moi

Kjetil K. Melby (f. 1946) er dr.med., avdelingsleder ved Avdeling for mikrobiologi, Klinikk for diagnostikk og intervensjon, Oslo universitetssykehus, og professor ved Institutt for klinisk medisin, Universitetet i Oslo.

Forfatter har fylt ut ICMJE-skjemaet og oppgir ingen interessekonflikter.

Anne O. Olsen (f. 1962) er overlege ved Olafiaklinikken, Oslo universitetssykehus, og førsteamanuensis ved Institutt for klinisk medisin, Universitetet i Oslo.

Forfatter har fylt ut ICMJE-skjemaet og oppgir ingen interessekonflikter.

Lumnije Dedi (f. 1953) er spesialist i medisinsk mikrobiologi og overlege ved Mikrobiologisk avdeling, Oslo universitetssykehus, Ullevål. Forfatter har fylt ut ICMJE-skjemaet og oppgir ingen interessekonflikter.

Peter Gaustad (f. 1944) er dr.med. og spesialist i medisinsk mikrobiologi. Han er seksjonsoverlege i bakteriologi ved Avdeling for mikrobiologi, Klinikk for diagnostikk og intervensjon, Oslo universitetssykehus, og professor ved Institutt for klinisk medisin, Universitetet i Oslo. Forfatter har fylt ut ICMJE-skjemaet og oppgir ingen interessekonflikter.

Gaute Syversen (f. 1959) er spesialist i medisinsk mikrobiologi og overlege ved Mikrobiologisk avdeling, Oslo universitetssykehus, Ullevål. Forfatter har fylt ut ICMJE-skjemaet og oppgir ingen interessekonflikter.

Harald Moi (f.1942) er spesialist i hud- og veneriske sykdommer, med spesialkompetanse i seksuelt overførbare infeksjoner. Han er professor emeritus ved Universitet i Oslo, overlege ved Olafiaklinikken, Oslo universitetssykehus, og medlem av komiteen som gir ut europeiske retningslinjer for kjønnssykdommer.

Forfatter har fylt ut ICMJE-skjemaet og oppgir ingen interessekonflikter.

Litteratur

1. Miller CP. Development of bacterial resistance to antibiotics. J Am Med Assoc 1947; 135: 749-51.

2. Phillips CW, Aller RD, Cohen SN. Penicillinaseproducing Neisseria gonorrhoeae. Lancet 1976; 2: 960.

3. Csángó PA, Gundersen T, Solberg VM et al. Amoxicillin i behandling av gonoré. En revisjon av de nasjonale anbefalinger. Tidsskr Nor Lægeforen 1986; 106: 2524-5, 2533. 
4. Melby K, Gundersen T, Ulshagen K. Amoxicillin i behandling av gonoré. Tidsskr Nor Laegeforen 1988; 108: 2397-8.

5. Melby K, Faegri A. The in vitro activity of norfloxacin, ofloxacin and ciprofloxacin and other antibiotics in current use against Neisseria gonorrhoeae. APMIS 1989; 97: 347-50.

6. Aavitsland P. Høiby EA. Behandling av ukomplisert gonoré hos voksne. Nye anbefalinger fra Arbeidsgruppen mot gonoré. Tidsskr Nor Lægeforen 1996; 116: 1577-80.

7. Bygdeman S, Bäckman M, Lidbrink P et al. Var återhållsam med kinolonbehandling vid gonorré risk för resistens. Läkartidningen 1990; 87: 2514.

8. Romøren M, Juvkam KJ, Moi H. Gonoré: Nasjonale faglige retningslinjer for antibiotikabruk i primærhelsetjenesten. 2012. Oslo: Helsedirektoratet, 2013: 171. www.helsebiblioteket.no/ retningslinjer/antibiotika/seksuelt-overf\%C3\% B8rbare-infeksjoner/gonor\%C3\%A9 (12.2.2014).

9. Unemo M, Golparian D, Syversen G et al. Two cases of verified clinical failures using internationally recommended first-line cefixime for gonorrhoea treatment, Norway, 2010. Euro Surveill 2010; 15: 19721.

10. Danielsson D. Hellbe L, Moi H. Spektinomycin mot okomplicerad urogenital gonorré. Läkartidningen 1978; 75: 2044-6.

11. Unemo M, Golparian D, Skogen V et al. Neisseria gonorrhoeae strain with high-level resistance to spectinomycin due to a novel resistance mechanism (mutated ribosomal protein S5) verified in Norway. Antimicrob Agents Chemother 2013; 57: 1057-61.

12. Moi H. Ny behandlingsanbefaling ved gonoré. Tidsskr Nor Legeforen 2013; 133: 1169.

13. Høiby EA, Vestrheim DF, Caugant DA et al. Bakteriell resistens mot antibiotika. Tidsskr Nor Legeforen 2008; 128: 2452-6.

14. Digranes A, Sjursen H, Melby KK et al. Antibiotic susceptibility of blood culture isolates of Enterobacteriaceae. A Norwegian multicenter study. APMIS 2001; 109: 641-6.

15. Karah N, Poirel L, Bengtsson S et al; Norwegian Study Group on PMQR. Plasmid-mediated quinolone resistance determinants qnr and aacl $\left.6^{\circ}\right)-\mathrm{lb}-\mathrm{cr}$ in Escherichia coli and Klebsiella spp. from Norway and Sweden. Diagn Microbiol Infect Dis 2010; 66: 425-31.

16. Spiteri G, Cole M, Unemo M et al. The European Gonococcal Antimicrobial Surveillance Programme (Euro-GASP)-a sentinel approach in the European Union (EU)/European Economic Area (EEA). Sex Transm Infect 2013; 89 (Suppl 4): iv16-8.

17. Unemo M, Nicholas RA. Emergence of multidrugresistant, extensively drug-resistant and untreatable gonorrhea. Future Microbiol 2012; 7: 1401-22

18. Sundar T. NORM skal varsle om resistente mikrober. Tidsskr Nor Lægeforen 2000; 120: 1256.

19. Universitetssykehuset Nord-Norge. Antibiotika og antibiotikaresistens. www.unn.no/antibiotikaresistens-no/category8924.html (10.2.2014).

Mottatt 8.1. 2014, første revisjon innsendt 23.1. 2014, godkjent 12.2. 2014. Redaktør: Matilde Risopatron Berg.

Publisert først på nett. 